\title{
A COMPARISON OF NONLINEAR MODELS FOR DESCRIBING WEIGHT- AGE DATA IN ANGLO-NUBIAN DOES ${ }^{1}$
}

\author{
FRANCISCO ARTHUR ARRÉ2 ${ }^{2}$ JOSÉ ELIVALTO GUIMARÃES CAMPELO² ${ }^{2}$ JOSE LINDENBERG ROCHA \\ SARMENTO $^{2}$, LUIZ ANTÔNIO SILVA FIGUEIREDO FILHO ${ }^{3}$, DIEGO HELCIAS CAVALCANTE ${ }^{4 *}$
}

\begin{abstract}
The objective of this study was to determine the optimum age at last weighing and compare the goodness of fit of nonlinear models used to fit longitudinal weight-age data to describe the growth pattern of Anglo-Nubian does. Weights of 104 animals from birth to 60 months of age were grouped into 10 age groups at six-month intervals. In each age group, parameters $A$ (asymptotic weight), $B$ (integration constant), and $K$ (maturity index) were estimated using the Brody, Gompertz, logistic, and von Bertalanffy models. Data were analyzed using analysis of variance in a factorial design (10 age groups $\times 4$ nonlinear models). The age group $\times$ model interaction was not significant. Mean estimates of $A, B$, and $K$ were significantly different between age groups up to 30 months $(\mathrm{p}<0.05)$, indicating that the estimated curve is affected by weights taken before this age independent of the model. The values of mean squared error (MSE), mean absolute deviation (MAD), coefficient of determination $\left(\mathrm{R}^{2}\right)$ and Rate of convergence (RC) at each age group up to 30 months were compared to determine the goodness of fit of nonlinear models. The ranking of fit was logistic, Brody, von Bertalanffy, and Gompertz. The logistic and Brody models respectively estimated the smallest and largest asymptotic weight. Longitudinal weight records taken until 30 months of age are most appropriate for estimating the growth of Anglo-Nubian does using nonlinear models.
\end{abstract}

Keywords: Anglo nubian. Weight gain. Age. Asymptotic weight. Growth rate.

\section{AJUSTE DE MODELOS NÃO LINEARES PARA DESCREVER CRESCIMENTO DE CABRAS COM PESAGENS EM DIFERENTES IDADES}

Resumo - Objetivou-se avaliar a idade da pesagem e a qualidade do ajuste de modelos não lineares a dados longitudinais para descrever o padrão de crescimento de fêmeas Anglonubiana. Pesos de 104 animais do nascimento até 60 meses de idade, foram agrupados em 10 classes, com intervalos de seis meses. Em cada classe estimou-se parâmetros $A, B$ e $K$ com modelos Brody, Gompertz, Logístico e Von Bertalanffy. Realizouse análise de variância com fatorial (10 classes x 4 modelos) com 104 repetições, considerando-se os três parâmetros como características. Baseou-se na significância da média dos parâmetros nas classes para identificar a melhor idade de pesagem. Não ocorreu interação "classe-modelos". As médias dos três parâmetros nas classes com pesos registrados até 30 meses diferiram entre si $(\mathrm{P}<0,05)$, indicando influência de pesagens inferior a essa idade na curva estimada, independente do modelo. Para identificar modelos com melhor ajuste aos dados, utilizou-se os valores do QMR, DMA, $\mathrm{R}^{2}$ e RC que cada um apresentou na classe com pesagens até 30 meses. Constatou-se como sequência de melhor ajuste: Logístico, Brody, Von Bertalanffy e Gompertz. O modelo Logístico estima menor peso assintótico e Brody o maior. Pesagens até 30 meses de idade se adequam à análise do padrão de crescimento de cabras com modelos não lineares.

Palavras-chave: Anglo nubiana. Ganho de peso. Idade. Peso assintótico. Taxa de crescimento.

\footnotetext{
"Corresponding author

${ }^{1}$ Received for publication in $04 / 03 / 2017$; accepted in 08/01/2018

Paper extracted from the master thesis of the first author.

${ }^{2}$ Department of Zootechnics, Universidade Federal do Piauí, Teresina, PI, Brazil;. arthurarre@hotmail.com - ORCID: 0000-0002-95354818, jelivalto@hotmail.com - ORCID: 0000-0001-5447-1084, sarmento@ufpi.edu.com.br - ORCID: 0000-0002-4215-1515.

${ }^{3}$ Department of Animal Science, Instituto Federal do Maranhão, Caxias, MA, Brazil.; luiz_medvet@hotmail.com - ORCID: 0000-00033204-1109.

${ }^{4}$ Department of Veterinary Medicine, Universidade Federal do Piauí, Bom Jesus, PI, Brazil; diegohelcias@hotmail.com - ORCID: 00000001-7881-1266.
} 


\section{INTRODUCTION}

Body weight is the most common parameter for modeling animal growth due to the ease of measurement in a large number of animals at a low cost. Nonlinear models that correlate body weight and age data to provide biologically interpretable parameters, such as the Brody, von Bertalanffy, Richards, logistic, and Gompertz functions, have been widely used to describe animal growth (SOUZA et al., 2013).

Breeding females make up the largest numbers in a herd and are usually replaced by young females from within the herd selected primarily for size. In small ruminants, the size of replacement females is important especially because they need to be physically able to carry the fetuses during gestation. However, selection for body weight may result in delayed maturity and a higher maintenance cost, which is not desirable for production in harsh environments such as semiarid regions, where animals may exhibit reduced performance and have a smaller size to adapt to the environment.

In goats, weights for growth studies using nonlinear models are usually taken before maturity is reached (OLIVEIRA et al., 2009), similarly to what occurs in sheep (SILVA, 2012; SOUZA et al., 2013; HOSSEIN-ZADEH, 2015). However, growth should be evaluated from birth to maturity to help determine the optimum slaughter age or to design feeding programs (BAHREINI-BEHZADI et al., 2014). Thus, breeders can take advantage of the knowledge on the growth dynamics of different tissues, which enables the selection of animals that are more productive at specific age and weight ranges (MOTA et al., 2015).

The use of growth curve parameters as selection criteria of replacement females is one practical application of nonlinear models. In fact, a negative correlation between estimates of the variables $A$ (asymptotic weight) and $K$ (maturity index) denotes early maturity and smaller mature weight (SARMENTO et al., 2006).

However, because females gain weight during gestation but lose weight during lactation (GONÇALVES et al., 2011) and because in goats the doe can breed before reaching mature weight, the longitudinal structure of data may affect model fitting as a result of heterogeneous variances.

The choice of most appropriate nonlinear model depends on several factors including, among others, the breed, location, age at last weighing, and type of model (SILVA et al., 2011). According to Guedes et al. (2004), to accurately estimate the weight-age relationship, a growth function must fulfil the criteria for reliability, accuracy, and operability, which correspond, respectively, to the: i) biological interpretability of parameters, ii) goodness of fit, and iii) computational ease.

This study aimed to determine the age at which does should be last weighed to accurately estimate growth curve parameters and compare the goodness of fit of nonlinear models used to fit weight-age data for Anglo-Nubian does.

\section{MATERIAL AND METHODS}

The study was conducted with Anglo-Nubian does from the Department of Zootechny, Center of Agrarian Sciences, Federal University of Piauí (DZO/CCA/UFPI) stock, located in Teresina, Piauí,

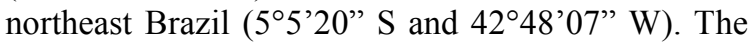
herd was formed by continuous breeding using purebred goats focusing on milk production traits rather than breed characteristics when selecting for replacement females.

Weight records of does born from January 2009 and entered in the herd database until 2016 were used for growth model analysis. To select animals of same physiological stage within a year and season (dry $\times$ rainy), breeding seasons were determined by grouping does into two groups with differing lactation times.

Fecal egg were counted every 40 days on average and animals were wormed with anthelmintics only when more than $10 \%$ of animals had an egg count greater than 1000 eggs per gram as recommended by Costa et al. (2011).

Goats were grazed on pasture from 08:00 h and returned to the pen at the end of the day, where they remained for the night and early morning when data were collected. Lactating does were collectively fed commercial feed with $16 \%$ crude protein during the study period to maintain body condition.

Goats were weighed biweekly up to weaning at approximately four months of age and subsequently at half-yearly intervals; pregnant does were weighed in the final third of gestation, one day after kidding, and at weaning at 120 days of age. Weights and their associated dates from other weighings were also entered in the database.

Mean live weights (mean \pm standard deviation, range) stratified by age of 247 AngloNubian does from the UFPI herd, of which 104 were used in the comparison of nonlinear growth models, are listed in Table 1. 
F. A. ARRÉ et al.

Table 1. Live weight (mean \pm SD, range) stratified by age of Anglo-Nubian does from the UFPI herd.

\begin{tabular}{lcc}
\hline Age & Mean weight $\pm \mathrm{SD}(\mathrm{kg})$ & Range $(\min -\mathrm{max}, \mathrm{kg})$ \\
\hline at birth & $2.8 \pm 0.5$ & $1.5-4.5$ \\
at weaning & $13.8 \pm 3.3$ & $8.5-8.1$ \\
1-2 years & $28.1 \pm 5.5$ & $16.0-44.0$ \\
$>$ 4 years & $42.3 \pm 6.3$ & $26.0-60.9$ \\
\hline
\end{tabular}

For the analysis of the goodness of fit of nonlinear models for predicting the growth of Anglo -Nubian does, we first determined the age at which does should last be weighed (longitudinal weightage data). For that, weight records of does weighed at birth and at $6,12,18,24,30,36,42,48,54$, and $\geq$ 60 months of age were grouped into 10 separate data files. Each file consisted of the weight records for one age group and files for older age groups included all records from younger age groups. Only does with weight records in all age groups were included, resulting in a final sample of 104 does. On average, there were 19.1 body weight records per doe with a minimum of 11 and a maximum of 41 records per animal used in the analysis of nonlinear growth models. The Brody, von Bertalanffy, logistic, and Gompertz functions were fitted to weight records (Table 2). Each model was fitted to the weight records of each doe individually using the modified Gauss-Newton method for nonlinear models described by Hartley (1961).

The parameter estimates of the four models were computed for each data file, where: $Y$ is body weight at age $t ; A$ is the asymptotic weight at infinite age; and $B$ is an integration constant determined by the initial values of $Y$ and $t$, which is related to initial weight but has no biological interpretation. $K$ is the maturity index, a measure of early maturity that expresses the rate at which the animal approaches a mature body size (FREITAS, 2005).

Table 2. Properties of the Brody, von Bertalanffy, logistic, and Gompertz functions. Instantaneous absolute growth rate (AGR) and weight at infection point.

\begin{tabular}{lccc}
\hline Model & General equation & $\begin{array}{c}\text { Absolute growth rate } \\
\text { (AGR) }\end{array}$ & $\begin{array}{c}\text { Weight at inflection } \\
\text { point }\end{array}$ \\
\hline Brody & $y=A\left(1-B \exp ^{-K t}\right)+\varepsilon$ & $K\left(A-\mathrm{y}_{\mathrm{t}}\right)$ & - \\
Von Bertalanffy & $y=A\left(1-B \exp ^{-K t}\right)^{3}+\varepsilon$ & $3 B K \mathrm{y}_{\mathrm{t}} \mathrm{e}^{-\mathrm{Kt}}\left(1-\mathrm{e}^{-\mathrm{Kt}}\right)^{-1}$ & $8 A / 27$ \\
Logistic & $y=A /\left(1+B \exp ^{-K t}\right)+\varepsilon$ & $K \mathrm{y}_{\mathrm{t}}\left(A-\mathrm{y}_{\mathrm{t}} / A\right)$ & $A / 2$ \\
Gompertz & $y=A \exp \left(-B \exp ^{-K t}\right)+\varepsilon$ & $K \mathrm{y}_{\mathrm{t}}\left(\log _{\mathrm{e}} A / \mathrm{y}\right)$ & $A / \mathrm{e}$ \\
\hline
\end{tabular}

Source: Freitas (2005)

Parameter estimates $(A, B$, and $K)$ for each animal were calculated using the PROC NLIN procedure of Statistical Analysis Software - SAS (2003) with the convergence criterion set at $10^{-8}$. The instantaneous absolute growth rate (AGR), which estimates the mean increment in weight per unit time, was also calculated to describe the growth of does.

Parameter estimates $A, B$, and $K$ of the four models and the following statistics were computed for each doe in each age group: a) mean squared error (MSE): measures the average of the squares of the errors, the average squared difference between the estimated and observed weights for each age group divided by the number of observations; b) mean absolute deviation (MAD), the sum of the absolute errors divided by the number of observations as proposed by Sarmento et al. (2006); c) coefficient of determination $\left(\mathrm{R}^{2}\right)$, the squared correlation of predicted and observed weights, and $\mathrm{d}$ ) Rate of convergence ( $\mathrm{RC})$, the number of animals that reached convergence in relation to the total number of animals.

To determine the optimum age at which does should last be weighed for the analysis of growth curves and whether there was an interaction between age groups and nonlinear models, parameters $A, B$, and $K$ of the four models were computed for each animal (individual growth rate) and analyzed using analysis of variance (ANOVA) in a completely randomized design and $10 \times 4$ factorial layout (age groups $\times$ nonlinear models) with 104 replicates (does). Mean parameter estimates for each age group were compared using the SNK test $(p<0.05)$. Significant differences in the variance of parameter estimates between age groups are indicative of changes in the parameter estimates and, consequently, the estimated curves.

The mean values of the MSE, MAD, $\mathrm{R}^{2}$ and $\mathrm{RC}$ were compared to determine the goodness of fit of each model based on the optimum age range over which growth curve parameters can be 
F. A. ARRÉ et al.

estimated. As an ancillary criterion, the standardized error distribution was analyzed graphically.

The AGR (kg/day) and the weight at the inflection point were calculated for each growth model to evaluate the absolute growth of AngloNubian does.

\section{RESULTS AND DISCUSSION}

Mean parameter estimates were compared across age groups to determine the optimum age range over which does should be weighed for the analysis of growth curves (Table 3 ).

Table 3. Comparison by the SNK test of mean ( $\pm \mathrm{SD}$ ) estimates of $A, B$, and $K$ stratified by age for the von Bertalanffy, Brody, Gompertz, and logistic models.

\begin{tabular}{lcccccc}
\hline \multirow{2}{*}{ Age in months } & \multicolumn{5}{c}{ Nonlinear model parameters* } \\
\cline { 2 - 7 } & $A$ & SD & $B$ & SD & $K$ & SD \\
\hline 6 & $20.02^{\mathrm{d}}$ & 10.26 & $1.65^{\mathrm{c}}$ & 1.31 & $0.0200^{\mathrm{a}}$ & 0.01 \\
12 & $19.75^{\mathrm{d}}$ & 8.22 & $1.67^{\mathrm{c}}$ & 1.37 & $0.0195^{\mathrm{a}}$ & 0.01 \\
18 & $24.28^{\mathrm{c}}$ & 10.46 & $1.82^{\mathrm{b}}$ & 1.58 & $0.0154^{\mathrm{b}}$ & 0.01 \\
24 & $28.41^{\mathrm{b}}$ & 10.11 & $2.00^{\mathrm{a}}$ & 1.80 & $0.0123^{\mathrm{c}}$ & 0.01 \\
30 & $29.69^{\mathrm{a}}$ & 10.08 & $2.04^{\mathrm{a}}$ & 1.85 & $0.0112^{\mathrm{d}}$ & 0.01 \\
36 & $30.34^{\mathrm{a}}$ & 10.29 & $2.05^{\mathrm{a}}$ & 1.88 & $0.0108^{\mathrm{d}}$ & 0.01 \\
42 & $30.76^{\mathrm{a}}$ & 10.57 & $2.06^{\mathrm{a}}$ & 1.89 & $0.0107^{\mathrm{d}}$ & 0.01 \\
48 & $30.96^{\mathrm{a}}$ & 10.48 & $2.04^{\mathrm{a}}$ & 1.87 & $0.0106^{\mathrm{d}}$ & 0.01 \\
54 & $30.92^{\mathrm{a}}$ & 10.35 & $2.04^{\mathrm{a}}$ & 1.88 & $0.0106^{\mathrm{d}}$ & 0.01 \\
60 & $30.93^{\mathrm{a}}$ & 10.29 & $2.06^{\mathrm{a}}$ & 1.90 & $0.0106^{\mathrm{d}}$ & 0.01 \\
\hline
\end{tabular}

*Means within a column followed by at least one same letter are not significantly different by the SNK test $(\mathrm{p}>0.05)$.

No significant differences were detected in mean estimates of $A$ and $K$ after 30 months of age and of $B$ after 24 months (p > 0.05, Table 3) indicating that the influence of age on growth parameters declined as age increased. Thus, these results indicate that, to determine the growth of the herd, the last weighing should be made at 30 months.

Mean age at first kidding is usually less than 30 months and, in our study, was $682 \pm 136$ days (mean $\pm \mathrm{SD}$ ). Even though we found no studies specifically aimed at determining the optimum age at which accurate estimates of nonlinear growth curve parameters can be estimated in goats, Morrow et al. (1978) found that growth curve parameters were accurately estimated in Angus cows weighed up to 54 months, i.e., after they reached reproductive age.

In addition, the distinctive weight gain that occurs during pregnancy and weight loss during lactation may result in a specific growth pattern for does. In fact, body weight and body measurements stabilize at an earlier age in does than in bucks and sexual dimorphism becomes more pronounced as age increases (TEIXEIRA NETO et al., 2013).
These findings clearly show that weight records taken from birth until at least 30 months of age provide accurate estimates of growth curve parameters in Anglo-Nubian does. This age range is wider than in most studies of nonlinear models in lambs (SARMENTO et al., 2006; MALHADO et al., 2009) and goats (FIGUEIREDO FILHO et al., 2012; OLIVEIRA et al., 2009; CARNEIRO et al., 2009; MALHADO et al., 2008), which used weights from birth to 12 months of age.

Table 4 shows the mean estimates of MSE, $\mathrm{MAD}, \mathrm{R}^{2}$, and convergence for weight records of Anglo-Nubian does from birth to 30 months of age used to determine the order of fit of the four nonlinear models. The $\mathrm{RC}$ and $\mathrm{R}^{2}$ values were similar across models (> 97\%). However the logistic and Brody functions had the lowest MSE and MAD values and yielded the best fit.

High $\mathrm{R}^{2}$ values $(0.97-0.98)$ were obtained for the four models, but the coefficient of determination has poor discriminatory power in selecting the best model compared to MSE, MAD, and RC (SILVA et al., 2011; SARMENTO et al., 2006). 
F. A. ARRÉ et al.

Table 4. Mean \pm SD of mean squared error (MSE), mean absolute deviation (MAD), coefficient of determination $\left(\mathrm{R}^{2}\right)$, rate of convergence (RC), and parameters $A, B$, and $K$ estimated by nonlinear models using weight records of 104 Anglo-Nubian does taken from birth to 30 months of age.

\begin{tabular}{lcccc}
\hline \multirow{2}{*}{ Parameter } & \multicolumn{4}{c}{ Non-linear model } \\
\cline { 2 - 5 } & von Bertalanffy & Brody & Gompertz & Logistic \\
\hline MSE & $1.6 \pm 1.45$ & $1.48 \pm 1.2$ & $1.69 \pm 1.5$ & $1.4 \pm 1.29$ \\
MAD & $0.81 \pm 0.4$ & $0.76 \pm 0.4$ & $0.85 \pm 0.5$ & $0.8 \pm 0.45$ \\
$\mathrm{R}^{2}$ & $0.98 \pm 0.016$ & $0.98 \pm 0.014$ & $0.98 \pm 0.016$ & $0.97 \pm 0.015$ \\
$\mathrm{RC}(\%)$ & 1.0 & 0.98 & 1.0 & 0.99 \\
$A$ & $31.35 \pm 10.5$ & $33.31 \pm 11.0$ & $31.06 \pm 8.9$ & $30.19 \pm 7.17$ \\
$B$ & $0.48 \pm 0.38$ & $0.89 \pm 0.39$ & $1.89 \pm 0.25$ & $4.86 \pm 1.38$ \\
$K$ & $0.006 \pm 0.005$ & $0.003 \pm 0.002$ & $0.008 \pm 0.0016$ & $0.012 \pm 0.09$ \\
$A \times K$ correlation & -0.74 & -0.66 & -0.78 & -0.81 \\
\hline
\end{tabular}

The spatial scatter of standardized residuals (Figure 1) confirms that the logistic, followed by the Brody model was superior and showed best fitness with residual error values ranging from -3 to +3 . The scatterplot revealed that residual error values were lower up to approximately 130 days of age in both the logistic and Brody models, which corresponds to weight records taken at similar time intervals. It should be noted that, according to Toral (2008), estimates of $A$ and $K$ for simulated weights reach the parametric values as the intervals between weighings become shorter and the number of weighings increases. This occurs because the correlation between simulated and estimated values decreases and the values of bias and mean squared errors increase as the number of weighings decrease.

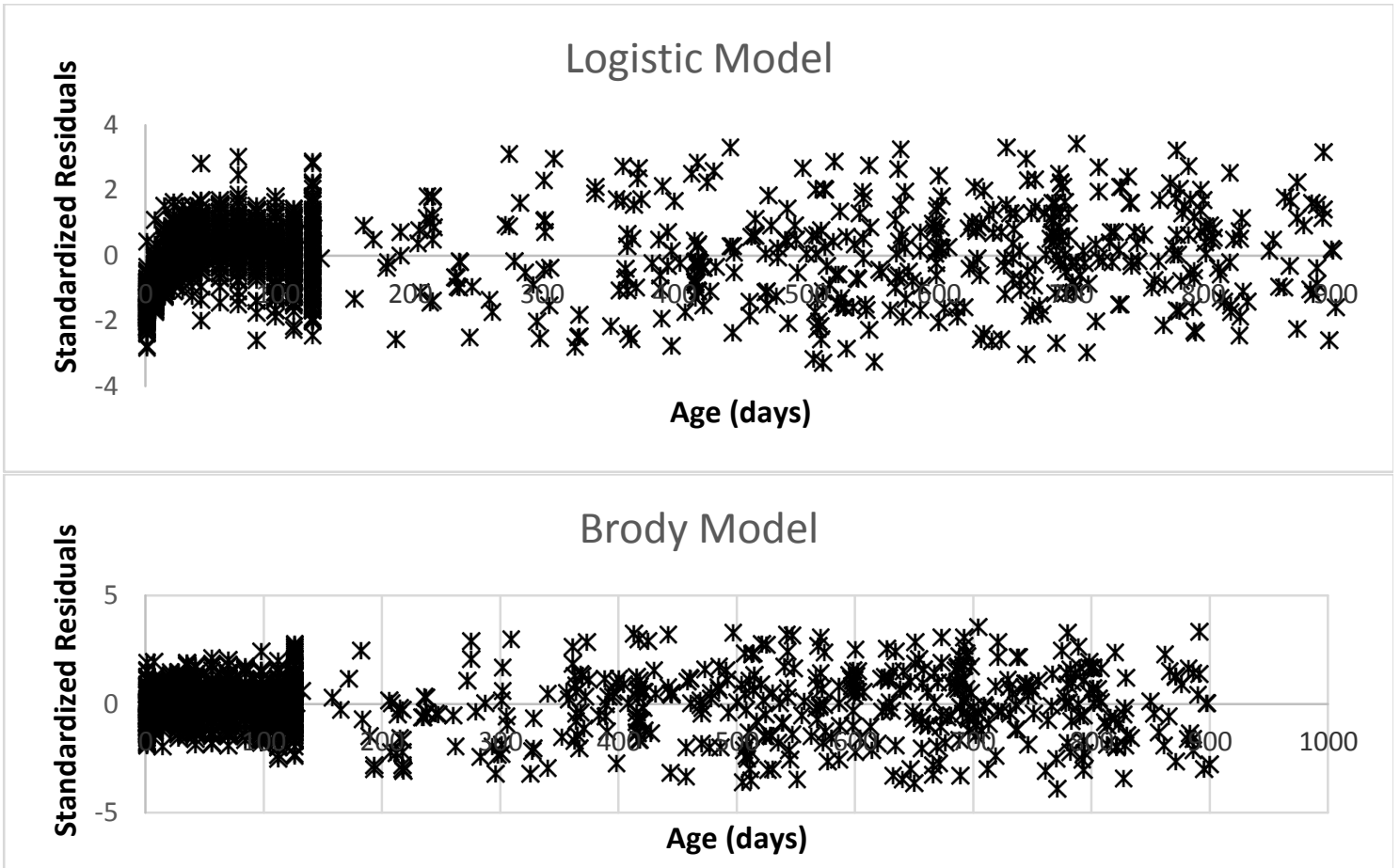

Figure 1. Scatterplot of standardized residuals estimated by the logistic and Brody models using weights of Anglo-Nubian does from birth to 30 months of age.

The most consistent fitness order of the four nonlinear models used to fit weight-age data for Anglo-Nubian does followed the following ranking: logistic, Brody, von Bertalanffy, and Gompertz. However, the emphasis on the logistic and Brody models can be explained by the fact that attention should be paid not only to the statistical aspect of growth-curve parameter estimates but also their biological interpretability (MENDES et al., 2008).

The asymptotic weight $(A)$ estimated by the von Bertalanffy and Gompertz functions using weights up to 30 months of age was lower than that of the Brody function, whereas the logistic yielded the lowest $A$ estimate of all models (Table 4). Similar 
results were reported in studies with cattle (BROWN; FITZHUGH JUNIOR; CARTWRIGTH, 1976; OLIVEIRA; LÔBO; PEREIRA, 2000), sheep (SARMENTO et al., 2006; SOUZA et al., 2011), and goats (OLIVEIRA et al., 2009), in which Brody yielded the highest estimates of $A$ and the logistic consistently yielded the lowest estimates of $A$.

The tendency of most models to underestimate asymptotic weight (Figure 2) should

be viewed in the context discussed by Brown, Fitzhugh Junior and Cartwrigth (1976)

, for whom asymptotic weight corresponds to the mean mature weight unaffected by seasonal effects rather than the maximum weight achieved by the animal, as underlined by Cavalcante et al. (2013) who analyzed weights taken before six months of age.

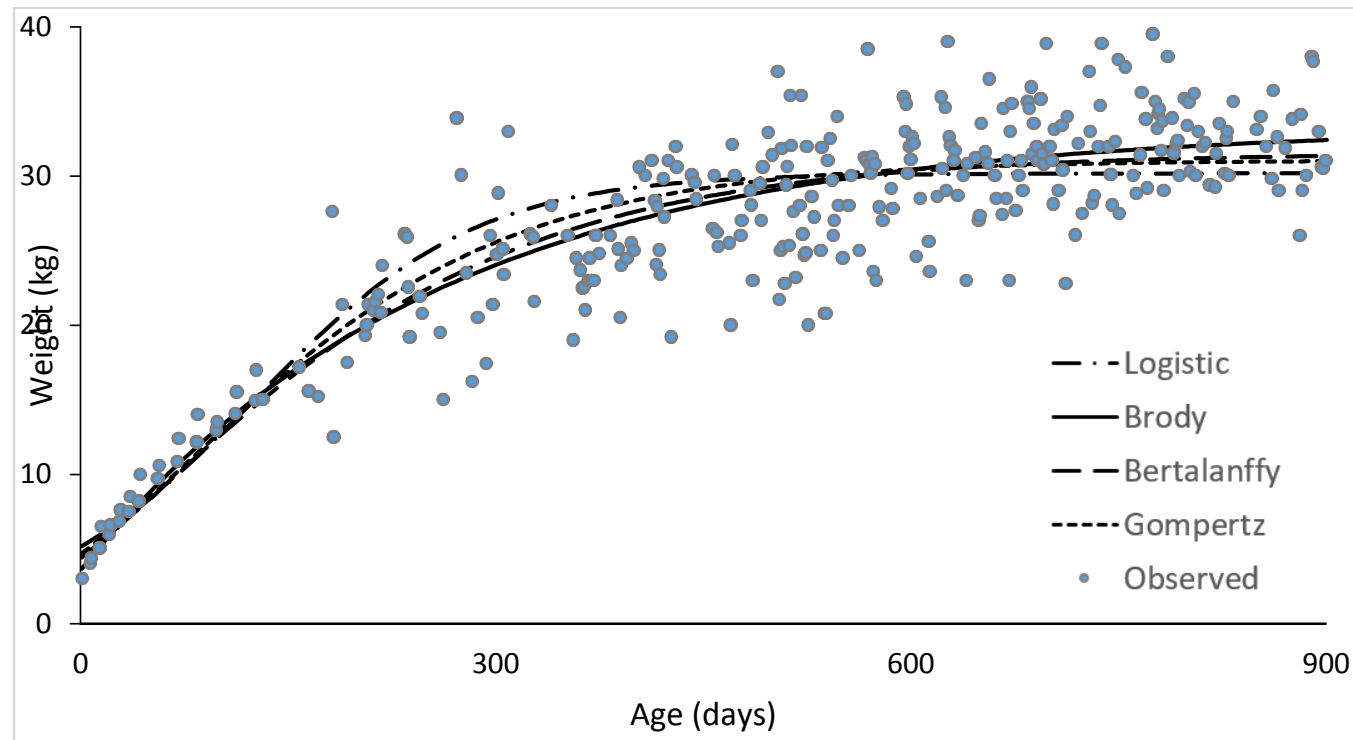

Figure 2. Growth curves estimated by the Brody, von Bertalanffy, Gompertz, and logistic models and scatter of observed weights in Anglo-Nubian does.

Estimates of $K$ correlated negatively with estimates of $A$ in the four models (Table 4). The logistic and Brody models yielded correlation coefficients of -0.81 and -0.66 , respectively, resulting in the lowest and highest estimates of mature weight for Anglo-Nubian does. According to Sarmento et al. (2006); Malhado et al. (2009), $K$ determines the speed with which the initial growth rate approaches the final growth rate and animals with highest $K$ values, which are associated with highest relative growth rates, have delayed maturity and are later in reaching mature weight. Thus, mature weight estimated by the Brody model $(K=$ 0.003 ) was achieved at a later age compared to the other models, and a similar pattern was observed in Morada Nova sheep (SOUZA et al., 2011).

Similar results were reported by Souza et al. (2013), who found correlation coefficients between $A$ and $K$ ranging from -0.87 to -0.44 and suggested that animals with higher growth rates are less likely to achieve higher mature weights compared to animals with lower growth rates at early life stages.

Knowledge of the correlation between estimates of $A$ and $K$ provides useful information in terms of feed management and to help determine the optimum slaughter age (OLIVEIRA et al., 2009; SOUZA et al., 2011; HOSSEIN-ZADE, 2015). According to Pacheco et al. (2008), knowledge of the factors that affect growth at each life stage can lead to the development of feed strategies to meet the animals' energy requirements and enhance growth.

The practical value of this information is more tangible when one considers that the pursuit of greater daily weight gains may lead to selection for large size, resulting in increased nutritional requirements to achieve the expected performance.

The correlation between $A$ and $K$ provides useful information that can also be used in guiding the replacement of does within the herd, because extreme weights are problematic in does: large ones have a high cost of maintenance, and despite their high growth potential, productivity may be low. Conversely, very small does, despite their low cost of maintenance, have progenies with low growth potential (MOTA et al., 2015), which specifically in goats may limit the ability of does to gestate and rear twin-born kids.

The instantaneous absolute growth rate (AGR) expressed as the mean weight increment per day is illustrated in Figure 3. Animals with higher $K$ values have higher growth rates. The AGR estimated by the logistic model predicted that does should gain weight at an initial rate of $51 \mathrm{~g} /$ day with a point of inflection at approximately 120 days of age. The logistic model had a mean weight gain of $98 \mathrm{~g}$ /day 
and the highest inflection point, but mature weight was achieved at an earlier age compared to the other models, because the AGR declined until 600 days and stabilized at an earlier age than in the other models. A similar pattern was observed in sheep by Souza et al. (2011) and Cavalcante et al. (2013).

The Brody model had no point of inflection (Figure.3) and the AGR declined steadily from approximately $120 \mathrm{~g}$ /day earlier in life to $40 \mathrm{~g} /$ day at
300 days of age.

The AGR estimated by the von Bertalanffy and Gompertz models predicted that Anglo-Nubian does should gain weight at an initial rate of $65 \mathrm{~g} /$ day up to a maximum $85 \mathrm{~g}$ /day at approximately 100 days of age, followed by a decline in weight gain that tended to stabilize at approximately 800 days of age.

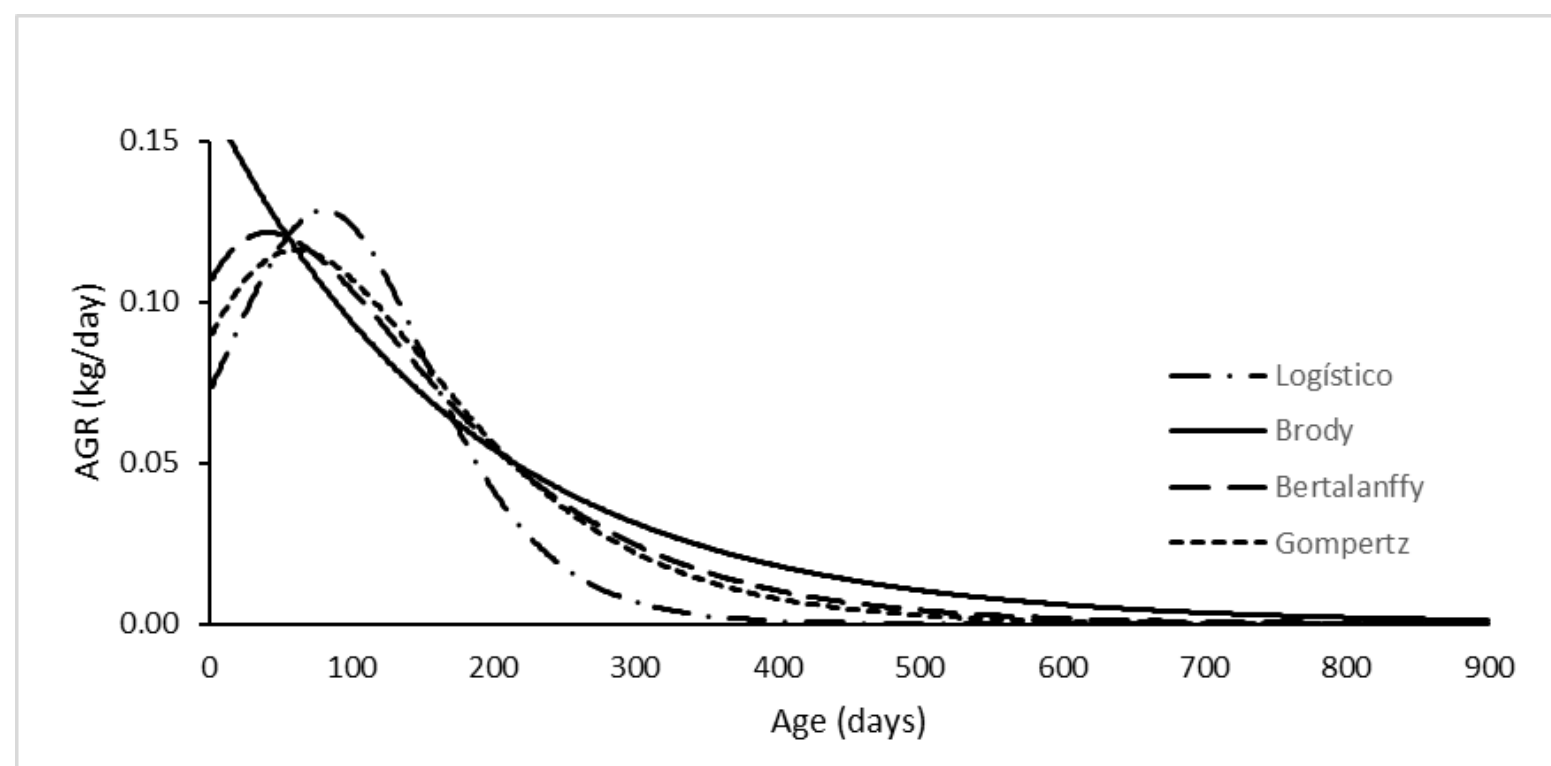

Figure 3. Instantaneous absolute growth rate (AGR, kg/day) estimated by the Brody, Von Bertalanffy, Gompertz, and logistic models in Anglo-Nubian does.

This result is in agreement with the growth curve of mammals, a sigmoid consisting of a prepubertal accelerating phase followed by a postpubertal decelerating phase (OWENS; DUBESKI; HANSON, 1993). A similar trend was observed in Anglo-Nubian goats by Oliveira et al. (2009), who found larger daily weight gains earlier in life, dropping from $194 \pm 42 \mathrm{~g}$ at 0-30 days to 91 $\pm 60 \mathrm{~g}$ at $210-240$ days, and that the logistic model more accurately estimated the growth curves for both males and females.

Similar results were reported for Morada Nova sheep by Souza et al. (2013), who found a sharp decline in weight gain after the inflection point. The authors underlined the need to improve the nutritional management of beef animals to minimize the effects of the change in diet at weaning and the postweaning weight losses while not affecting slaughter weight, because weight gain rate and feed conversion are greater at an early age when animals reach up to $30 \%$ of their mature weight.

\section{CONCLUSIONS}

Longitudinal weight records taken until at least 30 months of age are most appropriate for estimating the growth of Anglo-Nubian does using nonlinear models.

The logistic and Brody models showed best fitness and are the most appropriate for fitting weight-age data for Anglo-Nubian does.

\section{REFERENCES}

BAHREINI BEHZADI, M. R. et al. Comparison of mathematical models for describing the growth of Baluchi sheep. Journal Agriculture Science Technology, v. 14, n. 1, p. 57-68. 2014.

BROWN, J. E.; FITZHUGH JUNIOR, H. A.; CARTWRIGTH, T. C. A comparison of nonlinear models for describing weight age relationships in cattle. Journal of Animal Science, v. 42, n. 4, p. 810-818, 1976.

CARNEIRO, P. L. S. et al. Curva de crescimento em caprinos, da raça Mambrina, criados na caatinga. Revista Brasileira de Saúde e Produção Animal, v. 10, n. 3, p. 536-545. 2009.

CAVALCANTE, D. H. et al. Modelos não paramétricos para ajuste de curva de crescimento em 
caprinos Sem Raça Definida (SRD). Revista Acadêmica Ciências Agrárias, v. 11, n. 3, p. 283289, 2013.

COSTA, V. M. M. et al. Controle das parasitoses gastrintestinais em ovinos e caprinos na região semiárida do Nordeste do Brasil. Pesquisa Veterinária Brasileira, v. 31, n. 1, p. 65-71, 2011.

FIGUEIREDO FILHO, L. A. S. et al. Fatores ambientais e genéticos sobre a curva de crescimento de caprinos mestiços. Comunicata Scientiae, v. 3, n. 3, p. 154-161, 2012.

FREITAS, A. R. Curvas de crescimento na produção animal. Revista Brasileira de Zootecnia, v. 34, n. 3, p. $786-795,2005$.

GONÇALVES, T. M.; et al. Curva de crescimento de fêmeas da raça Nelore e seus cruzamentos. Ciência e Agrotecnologia, v. 35, n. 3, p. 582-590. 2011.

GUEDES, M. H. P. et al. Estudo das curvas de crescimento de cordeiros das raças Santa Inês e Bergamácia considerando heterogeneidade de variâncias. Ciência e Agrotecnologia, v. 28, n. 2, p. 381-388, 2004.

HARTLEY, H. O. The modified Gauss-Newton method for the fitting of non-linear regression functions by least squares. Thechnometrics, v. 3, n. 2, p. 269-280, 1961.

HOSSEIN-ZADEH, N. V. Modeling the growth curve of Iranian Shall sheep using non-linear growth models. Small Ruminant Research, v. 130, n. 1, p. 60-66. 2015.

MALHADO, C. H. M. et al. Curvas de crescimento para caprinos da raça Anglo-Nubiana criados na caatinga: rebanho de elite e comercial. Revista Brasileira de Saúde e Produção Animal, v. 9, n. 4, p. $662-671,2008$.

MALHADO, C. H. M. et al. Growth curves in Dorper sheep crossed with the local Brazilian breeds, Morada Nova, Rabo Largo, and Santa Inês. Small Ruminant Research, v. 84, n. 1-3, p. 16-21, 2009.

MENDES, P. N. et al. Modelo logístico difásico no estudo do crescimento de fêmeas da raça Hereford. Ciência Rural, v. 38, n. 7, p. 1984-1990, 2008.

MOTA, L. F. M. et al. Divergência morfométrica em bovinos Nelore em crescimento classificados para diferentes classes de Frame Size. Revista Caatinga, v. 28 , n. 2 , p. $117-125,2015$
OLIVEIRA, D. F. et al. Desenvolvimento ponderal e características de crescimento de caprinos da raça Anglonubiana criados em sistema semi-intensivo. Revista Brasileira Saúde Produção Animal, v. 10, n. 2 , p. $256-265,2009$.

OLIVEIRA, H. N.; LÔBO, R. B.; PEREIRA, C. S. Comparação de modelos não-lineares para descrever o crescimento de fêmeas da raça Guzerá. Pesquisa Agropecuária Brasileira, v. 35, n. 9, p. 1843-1851, 2000 .

OWENS, F. N.; DUBESKI, P.; HANSON, C. F. Factors that alter the growth and development of ruminants. Journal of Animal Science, v. 71, n. 11, p. 3138-3150. 1993.

PACHECO, A. et al. Medidas morfométricas de touros jovens e adultos da raça Guzerá. Revista Brasileira de Saúde e Produção Animal, v. 9, n. 3, p. 426-435. 2008.

SARMENTO, J.L.R. et al. Estudo da curva de crescimento de ovinos Santa Inês. Revista Brasileira de Zootecnia, v. 35, n. 2, p. 435-442, 2006.

SILVA, F. L. et al. Curvas de crescimento em vacas de corte de diferentes tipos biológicos. Pesquisa Agropecuária Brasileira, v. 46, n. 3, p. 262-271. 2011.

SILVA, L. S. A. et al. Growth curve in Santa Ines sheep. Small Ruminant Research, v. 105, n. 1-3, p. 182-185, 2012.

SOUZA, L. A. et al. Traditional and alternative non linear models for estimating the growth of Morada Nova sheep. Revista Brasileira de Zootecnia, v. 42, n. 9 , p. 651-655. 2013.

SOUZA, L. A. et al. Curvas de crescimento em ovinos da raça Morada nova criados no estado da Bahia. Revista Brasileira de Zootecnia, v. 40, n. 8 , p. 1700-1705. 2011.

TEIXEIRA NETO, M. R. et al. Parâmetros populacionais da raça ovina Santa Inês no Brasil. Pesquisa Agropecuária Brasileira, v. 48, n. 12, p. 1589-1595, 2013.

TORAL, F. L. B. Número e intervalo de pesagem para estimação de parâmetros de curvas de crescimento em bovinos. Revista Brasileira de Zootecnia, v. 37, n. 12, p. 2120-2128, 2008 